\title{
Ozone Therapy for Tumor Oxygenation: a Pilot Study
}

\author{
Bernardino Clavo ${ }^{1,5}$, Juan L. Pérez ${ }^{2,5}$, Laura López ${ }^{1,5}$, Gerardo Suárez ${ }^{1,5}$, Marta Lloret 1,5, Victor Rodríguez ${ }^{3}$, David \\ Macías $^{2,5}$, Maite Santana ${ }^{1}$, María A. Hernández ${ }^{1,5}$, Roberto Martín-Oliva ${ }^{2}$ and Francisco Robaina ${ }^{4,5}$ \\ ${ }^{1}$ Radiation Oncology and Research Unit, ${ }^{2}$ Medical Physics, ${ }^{3}$ La Paterna Medical Center, ${ }^{4}$ Chronic Pain Unit, Dr Negrín \\ Hospital and ${ }^{5}$ Canary Islands Institute for Cancer Research (ICIC), Las Palmas (Canary Islands), Spain
}

\begin{abstract}
Tumor hypoxia is an adverse factor for chemotherapy and radiotherapy. Ozone therapy is a nonconventional form of medicine that has been used successfully in the treatment of ischemic disorders. This prospective study was designed to assess the effect of ozone therapy on tumor oxygenation. Eighteen subjects were recruited for the study. Systemic ozone therapy was administered by autohemotransfusion on three alternate days over one week. Tumor oxygenation levels were measured using polarographic needle probes before and after the first and the third ozone therapy session. Overall, no statistically significant change was observed in the tumor oxygenation in the 18 patients. However, a significant decrease was observed in hypoxic values $\leq 10$ and $\leq 5 \mathrm{mmHg}$ of $\mathrm{pO}_{2}$. When individually assessed, a significant and inverse non-linear correlation was observed between increase in oxygenation and the initial tumor $\mathrm{pO}_{2}$ values at each measuring time-point, thus indicating that the more poorly-oxygenated tumors benefited most (rho $=-0.725 ; P=0.001$ ). Additionally, the effect of ozone therapy was found to be lower in patients with higher hemoglobin concentrations (rho $=-0.531 ; P<0.034$ ). Despite being administered over a very short period, ozone therapy improved oxygenation in the most hypoxic tumors. Ozone therapy as adjuvant in chemo-radiotherapy warrants further research.
\end{abstract}

Keywords: cancer - hypoxia $-\mathrm{pO}_{2}$ measurement - polarographic probe

\section{Introduction}

Tumor hypoxia can cause an increase in radio-resistance by up to $2.5-3$ times (1) and predisposes a physiologic selection of tumor cells with decreased apoptosis. This results in additional resistance to radiotherapy and chemotherapy (2) and further increase in angiogenesis and a more aggressive tumor potential (3-5).

Tumor hypoxia, when assessed by polarographic probes, is an independent prognostic factor for response to treatment and/or survival of head and neck tumors (6-9) and uterine cervical tumors $(10,11)$ as well as sarcomas $(12,13)$. The polarographic probe technique was designated as 'gold standard' for tumor $\mathrm{pO}_{2}$ measurement in a special workshop sponsored by the National Cancer Institute (14), at which the importance of developing methods to overcome tumor hypoxia was emphasized. Since then, meta-analyses have

For reprints and all correspondence: Bernardino Clavo, Department of Radiation Oncology and Research Unit, Dr Negrín Hospital, C/ Barranco la Ballena s/n, 35020 Las Palmas (Canary Islands), Spain. Fax: (+34) 928 449127; Tel: (+34) 928 450284. E-mail: bernardinoclavo@terra.es demonstrated that hypoxia modification during radiotherapy can improve treatment outcomes (15).

Ozone therapy has been shown to be beneficial to patients with ischemic disorders, particularly of the lower limbs (1618). In our previous studies we had found that ozone therapy increases oxygenation in the most poorly-oxygenated tissues of the anterior tibialis muscles (19) and that oxygenation in these muscles might be related to tumor oxygenation (20).

The objective of the present preliminary (and prospective) study is to evaluate the effect of ozone therapy on tumor oxygenation, using the polarographic probe measurement technique.

\section{Subjects and Methods}

\section{Patients}

Eighteen patients with accessible metastases or advanced tumors were enrolled in the study (14 with head and neck tumors, 2 with gynecological tumors and two bone metastases in chest wall region). Patients comprised 15 males and 3 females with mean age of 64 years (range, 50-91). The selection criteria included the following: a minimum age of 18 
Table 1. Characteristics of the patients and their tumors

\begin{tabular}{|c|c|c|c|c|c|c|c|c|c|}
\hline Patient & Age & Location & Stage & Size & $\mathrm{Hb}$ & $\mathrm{pO}_{2}$ pre-1 & $\mathrm{pO}_{2}$ post-1 & $\mathrm{pO}_{2}$ pre-3 & $\mathrm{PO}_{2}$ post-3 \\
\hline 1 & 70 & Maxillary bone relapsed chondrosarcoma & & $4 * 4$ & 13.4 & 1 & N.A. & 33.9 & 21.9 \\
\hline 2 & 60 & Vulva, relapsed & & & NA & 36 & 47.3 & 11.5 & 11.9 \\
\hline 4 & 63 & Hypopharynx & T4 N2a M0 & $5.5 * 5.5$ & 12.1 & 17 & N.A. & 29.0 & 29.5 \\
\hline 5 & 91 & Hodgkin disease & II-A & $9 * 6$ & 10.8 & 3 & 9.1 & 18.1 & 9.7 \\
\hline 6 & 51 & Thyroid Medullar carcinoma & T4 N1 M1 & $10 * 7$ & 13.4 & 29 & 38.8 & 31.5 & 34.1 \\
\hline 8 & 50 & Vagina & T3 N0 M0 & & 13.2 & 2 & 4.7 & 24.2 & 19.3 \\
\hline 9 & 60 & Oropharynx, relapsed & & $3 * 3$ & 14.0 & 38 & 39.6 & 39.0 & 32.0 \\
\hline 10 & 76 & Chest wall metastases clear cell carcinoma & Tx Nx M1 & $6 * 6$ & 13.3 & 43 & 48.5 & 39.6 & 18.9 \\
\hline 11 & 69 & Chest wall metastases hepatocellular carcinoma & T3 N0 M1 & $10 * 8$ & NA & 29 & 42.9 & 34.4 & 34.0 \\
\hline 12 & 65 & Oesophagus, relapsed & & $3 * 3$ & 10.8 & 1 & 31.8 & 3.1 & 30.9 \\
\hline 16 & 63 & Supraglottis & T2 N3 M0 & $8.5 * 5.5$ & 13.6 & 3 & 9.9 & 13.2 & 4.3 \\
\hline 17 & 67 & Oral cavity & T4 N3 M0 & $8.5 * 5.5$ & 14.7 & 1 & 2.2 & 1.3 & .9 \\
\hline 18 & 71 & Cervical metastases from UPT & Tx N3 M1 & $12 * 7.5$ & 15.6 & 17 & 17.1 & 9.0 & 13.9 \\
\hline
\end{tabular}

Stage; $\mathrm{T}=$ Tumor; $\mathrm{N}=$ Node: according to AJCC cancer staging manual, 5 th edition. Size $=$ largest diameter clinically measured (in $\mathrm{cm}$ ). All $\mathrm{pO}_{2}$ measurements were in the largest node. UPT $=$ unknown primary tumor. $\mathrm{pO}_{2}$ pre- $1=\mathrm{pO}_{2}$ before session $\# 1=$ basal. $\mathrm{pO}_{2}$ post-1 $=\mathrm{pO}_{2}$ after session $\# 1$. pO $\mathrm{O}_{2}$ pre- $3=$ $\mathrm{pO}_{2} 48 \mathrm{~h}$ after session \#2 and before session \#3. $\mathrm{pO}_{2}$ post-3 $=\mathrm{pO}_{2}$ after session 3. N.A. = not available.

years, Karnofsky performance status of $>70 \%$, cancer diagnosis histologically confirmed with metastases or advanced tumors accessible to physical examination and not being suitable for surgical resection. The mean of measured tumors/ nodes was $6.5 \mathrm{~cm}$ across the greatest diameter (range, 3-12 $\mathrm{cm})$. The exclusion criteria included the following: unwillingness to participate in the study, treatment with experimental or evaluation drugs during the planned study or not fulfilling all of the selection criteria described above. The experimental nature of the study was explained in detail and informed consent was obtained from all patients prior to study. The study was approved by the Institutional Ethical Committee.

\section{Ozone Therapy}

Ozone therapy was administered by autohemotransfusion on three alternate days over one week. The procedure involved the extraction of $200 \mathrm{ml}$ venous blood into heparin (25 IU/ $\mathrm{ml})$ and $\mathrm{CaCl}_{2}(5 \mathrm{mM})$. Using clinical-grade $\mathrm{O}_{2}$, the $\mathrm{O}_{3} / \mathrm{O}_{2}$ gas mixture was prepared with an OZON 2000 device (Zotzmann + Stahl GmbH, Plüderhausen, Germany) and sterilized by passing it through a sterile $0.20-\mu \mathrm{m}$ filter. The blood was mixed with $200 \mathrm{ml}$ of the $\mathrm{O}_{3} / \mathrm{O}_{2}$ gas mixture at a concentration of $60 \mu \mathrm{g} / \mathrm{ml}$, in a single-use sterile container with a capacity of $300 \mathrm{ml}$. Following this, it was slowly re-introduced into the patient's body. The blood had been extra-corporeal for about 15-30 minutes but no adverse reactions were observed. Table 1 summarizes some of the most relevant clinical characteristics of the patients.

\section{Tumor $\mathrm{pO}_{2}$ Measurement}

Tumor oxygenation was measured using a polarographic probe system: the ' $\mathrm{pO}_{2}$ Histograph' (Eppendorf AG, Hamburg, Germany). The details of this technique have been described previously (21). Briefly, a $0.5 \mathrm{~mm}$ diameter electrode $(0.3 \mathrm{~mm}$ diameter at the tip) is inserted into the tumor while the patient is under subcutaneous anesthesia. The movement is computer controlled and consists of a $1 \mathrm{~mm}$ forward motion and a $0.3 \mathrm{~mm}$ backward motion to avoid tissue compression at the measurement site. $\mathrm{A} \mathrm{pO}_{2}$ value is obtained at every $0.7 \mathrm{~mm}$. For each set of measurements obtained, 150-200 single $\mathrm{pO}_{2}$ values were automatically recorded using at least six different electrode tracks. To determine tumor oxygenation, median $\mathrm{pO}_{2}$ and the percentage of $\mathrm{pO}_{2}$ values $\leq 10 \mathrm{mmHg}$ and $\leq 5 \mathrm{mmHg}$ were obtained from the pooled data for each individual.

Tumor oxygenation values were obtained on four occasions: First, before session \#1; second, after session \#1; third, $48 \mathrm{~h}$ after session $\# 2$ and before session \#3; fourth, after session \#3.

For each tumor, the change in oxygenation $\left(\Delta \mathrm{pO}_{2}\right)$ was calculated as the $\mathrm{pO}_{2}$ value at each time-point relative to the pre-session \#1 ('baseline') $\mathrm{pO}_{2}$ value.

The measurements were carried out on accessible, clinically palpable lymph nodes or subcutaneous metastases without using an imaging technique. 


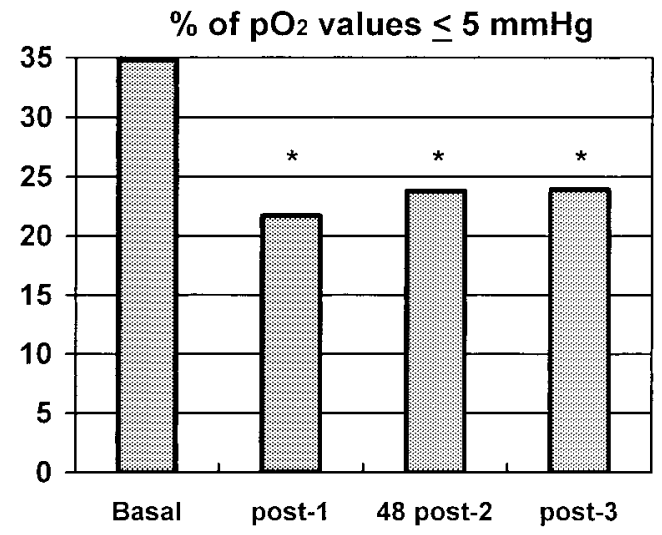

Figure 1. Change in percentage of $\mathrm{pO}_{2}$ values $\leq 5 \mathrm{mmHg}$. During ozone therapy, a decrease in percentage of $\mathrm{pO}_{2}$ values $\leq 5 \mathrm{mmHg}$ at each measurement time-point was observed in the tumors of patients: Baseline $=$ before ozone therapy; post $-1=$ after session \#1 $(P=0.002) ; 48$ post $-2=48 \mathrm{~h}$ after session \#2 $(P=0.045)$; post $-3=$ after session \#3 $(P=0.033)$. Significant differences $(P<0.05)$ are indicated with an asterisk $(*)$

\section{Statistical Analysis}

The SPSS 11.0 for Windows software package was used for this study. The distribution of data was assessed by the Kolgomorov-Smirnov test. Two-tailed tests were applied for significance. The paired t-test was used to compare means of all the median tumor values and all the percentages of the $\leq 10$ and $\leq 5 \mathrm{mmHg}$ measurements. These data are expressed as means $\pm \mathrm{SD}$. The Mann-Whitney $\mathrm{U}$ test was used to compare the $\Delta \mathrm{pO}_{2}$ between tumors above and below the median baseline $\mathrm{pO}_{2}$. These data are expressed as median and $25 \%$ $75 \%$ inter-quartile interval. Linear correlation was assessed by Pearson's $r$ test and non-linear correlation by Spearman's rho test. Differences were considered significant at the $P<$ 0.05 level.

\section{Results}

\section{Tumor Oxygenation}

The patient's individual data for hemoglobin levels and $\mathrm{pO}_{2}$ values at each measurement time-point are shown in Table 1. Initial tumor oxygenation was $23 \pm 5.1 \mathrm{mmHg}$, and was not related to sex, age, hemoglobin levels, clinical status or tumor size.

After session \#1 tumor oxygenation was $31.9 \pm 5.1 \mathrm{mmHg}$, and this difference was significant, $P=0.009$. However, no statistically significant differences were found in the other two measurement time-point: $48 \mathrm{~h}$ after session \#2 (27.3 \pm $4.3 \mathrm{mmHg})$ and after session $3(25.1 \pm 3.9 \mathrm{mmHg})$.

\section{Hypoxic Values}

The percentage of values $\leq 10 \mathrm{mmHg}$ at the baseline proceeded to decrease significantly during ozone therapy from $40.8 \pm 7.3 \%$ to $27.4 \pm 7.3 \%(P=0.002)$ after session \#1 and to $29 \pm 6.2 \%(P=0.039) 48 \mathrm{~h}$ after session $\# 2$. The decrease

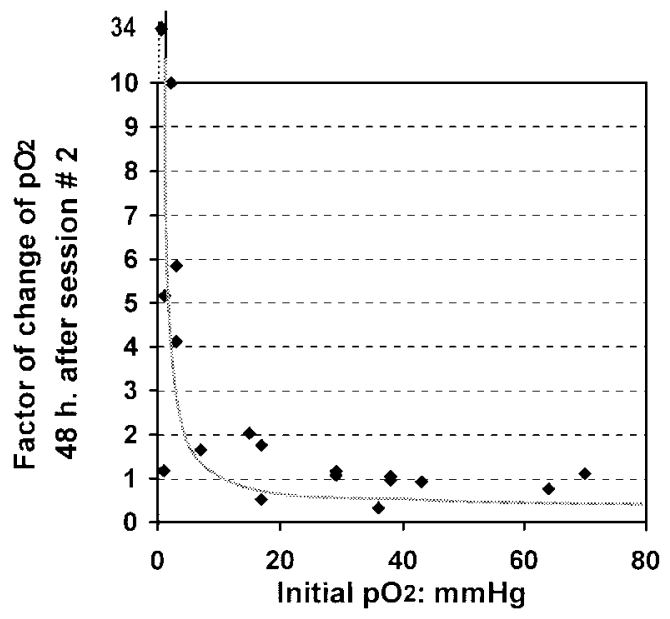

Figure 2. Factor of change in $\mathrm{pO}_{2}\left(\Delta \mathrm{pO}_{2}\right)$ and initial $\mathrm{pO}_{2}$ For each participant, the $\Delta \mathrm{pO}_{2}$ was calculated as the $\mathrm{pO}_{2}$ value at each time-point relative to the baseline $\mathrm{pO}_{2}$ value measured before the start of the ozone therapy. A non-linear correlation was found between baseline $\mathrm{pO}_{2}$ and $\Delta \mathrm{pO}_{2}$ at each measurement time-point. The figure shows an inverse correlation (rho = -0.798 ) after session \#3 of ozone therapy, which indicates that the highest therapy-associated changes in tumor $\mathrm{pO}_{2}$ occurred in tumors with the poorest baseline oxygenation. $\mathrm{A} \Delta \mathrm{pO}_{2}$ value $<1$ signifies decrease in oxygenation and $\Delta \mathrm{pO}_{2}>1$ signifies an increase in tumor oxygenation after session \#3.

to $31 \pm 5.1 \%$ after session \#3 did not qualify as statistical significance $(P=0.058)$.

The percentage of values $\leq 5 \mathrm{mmHg}$ at the baseline proceeded to decrease significantly during ozone therapy from $34.8 \pm 7.5 \%$ to $21.7 \pm 6.9 \%(P=0.002)$ after session \#1, to $23.8 \pm 5.9 \%(P=0.045) 48 \mathrm{~h}$ after session 2 and to $23.9 \pm$ $4.9 \%(P=0.033)$ after session \#3 (Fig. 1).

\section{Factor of Change of $\mathrm{pO}_{2}\left(\Delta \mathrm{pO}_{2}\right)$ :}

At each measurement time-point, an inverse and non-linear correlation was found between individual $\Delta \mathrm{pO}_{2}$ and initial $\mathrm{pO}_{2}$ values. A higher $\Delta \mathrm{pO}_{2}$ was observed in those tumors that had had lower initial $\mathrm{pO}_{2}$ values. Significant changes were observed after session \#1 (rho $=-0.812, P<0.001), 48 \mathrm{~h}$ after session \#2 (rho $=-0.798, P<0.001)$ and after session $\# 3$ (rho $=-0.725, P=0.001$ ) (Fig. 2).

This was corroborated by the comparison of $\Delta \mathrm{pO}_{2}$ between tumors above and below the median $\mathrm{pO}_{2}$ prior to ozone therapy (baseline), at each measurement time-point. While the initially well-oxygenated tumors (those above the median) showed oxygenation decrease, the initially most poorlyoxygenated tumors (those below the median) showed an increase in oxygenation after the ozone therapy. The changes recorded were a factor of 2.5 (range, $2-3.1 ; P=0.002$ ) after session \#1, a factor of 4.1 (range, $1.7-8 ; P<0.001$ ) $48 \mathrm{~h}$ after session \#2, and a factor of 2.9 (range, $1.1-15 ; P=0.002$ ) after session \#3 (Fig. 3).

Further, at each measurement time-point, an inverse, nonlinear correlation between individual $\Delta \mathrm{pO}_{2}$ and hemoglobin levels was found. The $\Delta \mathrm{pO}_{2}$ in tumors was lower in patients with higher hemoglobin levels after session \#1 (rho $=-0.650$, 


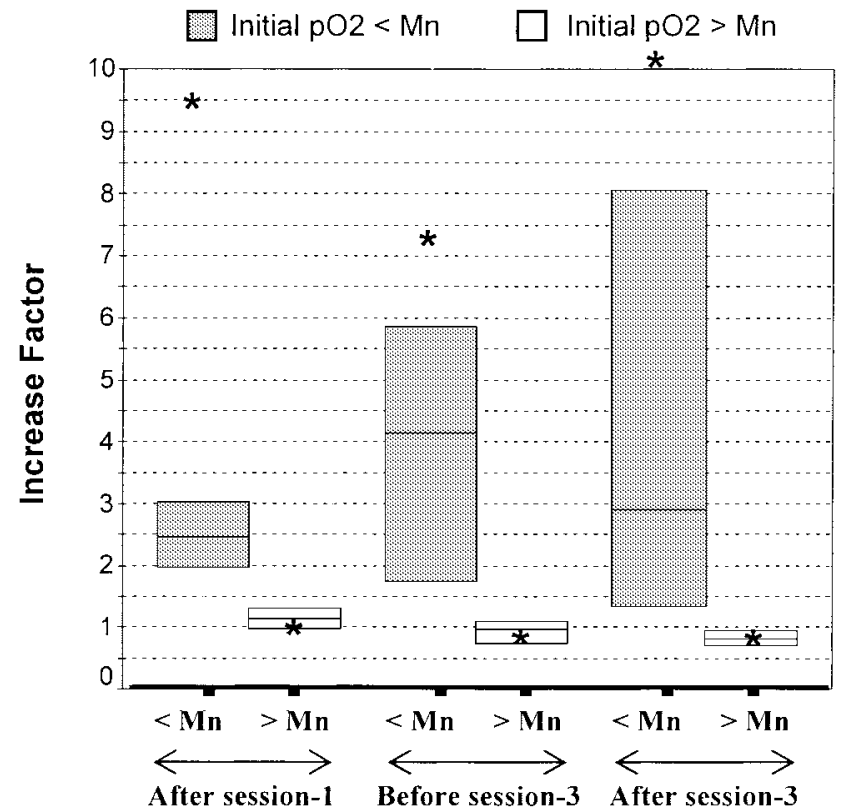

Figure 3. Factor of change of $\mathrm{pO}_{2}\left(\Delta \mathrm{pO}_{2}\right)$ segregated with respect to the initial median $\mathrm{pO}_{2}$. The figure shows the $\Delta \mathrm{pO}_{2}$ at each measurement time-point following ozone therapy and segregated with respect to baseline $\mathrm{pO}_{2}$ value above or below the median $\mathrm{pO}_{2}$ value $(17 \mathrm{mmHg}$ ) of the overall study group. The boxes show the $25 \%-75 \%$ inter-quartile interval, which includes the $50 \%$ values. The horizontal lines in the boxes represent the median and the * represents the mean of $\Delta \mathrm{pO}_{2}$ for both groups of tumors at each measurement time-point. During ozone therapy, well-oxygenated tumors (baseline $\mathrm{pO}_{2}$ above the median) showed no change ( $\Delta \mathrm{pO}_{2}$ approximately 1$)$ or even decrease after session \#3 $\left(\Delta \mathrm{pO}_{2}=0.8\right)$. However the most "poorly-oxygenated' tumors (baseline $\mathrm{pO}_{2}$ below the median) showed increase in tumor oxygenation $\left(\Delta \mathrm{pO}_{2}>1\right)$. These differences were significant at all the three measurement time-points ( $P=0.002,0.001$ and 0.002 , respectively). $<$ Median $=$ tumors with baseline $\mathrm{pO}_{2}$ values below the median value; $>$ Median $=$ tumors with baseline $\mathrm{pO}_{2}$ values above the median value .

$P=0.012), 48 \mathrm{~h}$ after session $\# 2$ (rho $=-0.531, P=0.034)$ and after session \#3 (rho $=-0.579, P=0.019$ ) (Fig. 4).

\section{Discussion}

Ozone $\left(\mathrm{O}_{3}\right)$ is the allotropic form of oxygen with three atoms and two unpaired electrons, which has a higher oxidizing capacity than oxygen. In order to avoid lung toxicity, medical applications of ozone require to preclude airways involvement. Autohemotransfusion fulfils this requirement. In appropriate concentrations, this technique leads to a transient oxidative stress that can stimulate blood antioxidants by up-regulation (22-24). This mechanism has been ascribed to ozone therapy's protection against free radical damage of heart (22), and prevention of renal (25) and hepatic (26) disorders. Hemolysis of $<2.5 \%$ and an acceptable level of lipid peroxide formation has been described in autohemotransfusion at $\mathrm{O}_{3} / \mathrm{O}_{2}$ concentrations of $60 \mu \mathrm{g} / \mathrm{ml}$ (23).

The objective of the present study was to assess whether changes in tumor oxygenation occurred during ozone therapy. Each patient served as his own control and elective nonozonated autohemotransfusion was not performed in a sepa-

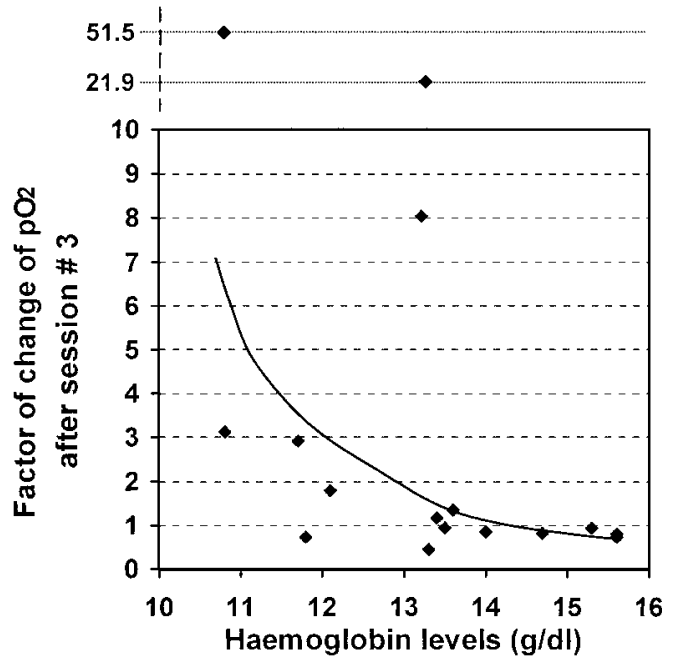

Figure 4. Factor of change of $\mathrm{pO}_{2}\left(\Delta \mathrm{pO}_{2}\right)$ after session \#3 and hemoglobin levels. There was an inverse and non-linear correlation between hemoglobin levels and the $\mathrm{p}_{2}$ at each measurement time-point following ozone therapy, i.e., a lower effect of ozone therapy was observed in patients with higher hemoglobin levels. The figure shows the correlation with the $\Delta \mathrm{pO}_{2}$ after session \#3 (rho $=-0.579, P=0.019$ ).

rate control group. It was not considered ethical for these advanced cancer patients to undergo invasive study-manipulations over several days in a control group which, theoretically, did not offer any potential benefit (transfusion of oxygenated blood is not a therapeutical approach). On the other hand, several studies have already demonstrated that the administration of ozone-free oxygen in a control group does not produce the 'prooxidant/antioxidant' response necessary to mediate the clinical effects of ozone therapy. This reaction was produced only when ozone was added to oxygen in equimolar amounts $(18,24$ and 26$)$.

In the course of ozone therapy by autohemotransfusion, ozone, per se, does not enter the organism, and its effects are mediated by rapid (a matter of seconds) oxidation of blood components in the transfusion recipient. The oxidized molecules and the specific antioxidant generated would vary according to the levels of ozone therapy. The vascular effect of ozonated blood transfusion is explained by an increase of malonyldialdehyde and lipid peroxidation leading to leading to activation of the hexose monophosphate shunt with an increased production of 2,3-diphosphoglycerate in erythrocytes (27). This results in a displacement of the oxyhemoglobin dissociation curve to the right and an increase in the release of oxygen to the tissues. A pH decrease in erythrocytes may also shift the oxyhemoglobin dissociation curve to the right (Bohr effect) without modification of 2,3-diphosphoglycerate (28). Furthermore, a charge modification in red cell membranes results in an improvement in membrane flexibility and a decrease in blood viscosity and resistance $(18,29)$. Adenosine, prostaglandins and, especially, nitric oxide release could collaborate in affecting the micro-circulation and lead to a decrease in vascular resistance (30).

Overall, ozone therapy decreased the percentage of values $\leq 10$ and $\leq 5 \mathrm{mmHg}$ at each measurement time-point. How- 
ever, no increase was observed in tumor $\mathrm{pO}_{2}$, as has been reported in an animal study (31). In the present study, the oxygenation decreased in tumors with $\mathrm{pO}_{2}$ concentrations above the median. Based on the oxygen radio-sensitivity curve, it can be inferred that this is not of clinical relevance in well-oxygenated tumors. However, in tumors with baseline $\mathrm{pO}_{2}$ below the median, i.e. tumors in which the radio-resistance could increase in relation to this 'adverse' value, ozone therapy actually increased the tumor $\mathrm{pO}_{2}$. This effect is similar to that observed by us (19) in anterior tibialis muscle tissues following the administration of ozone therapy.

The mechanisms underlying this effect in tumors have yet to be defined. Based on previously described effects, we hypothesize that the inverse correlation between initial oxygenation and $\mathrm{pOO}_{2}$ in tumors and tissues during ozone therapy is secondary to blood flow redistribution, i.e., a drop in blood flow in well-oxygenated tissues in favor of less welloxygenated tissues. Tumor vessels have structural and functional abnormalities with decreased or absent auto-regulatory mechanisms (32). Hence, an improvement in blood rheologic parameters, as described by other authors $(18,29)$, could play an important role in the effect of ozone therapy in high-resistance systems such as in tumors; this could apply to at least the areas of the tumor that are most hypoxic. Congruent with this concept is the improvement we observed with ozone therapy in patients with lower hemoglobin levels and, as a consequence, with lower blood viscosity. This vascular effect is further supported by our preliminary studies with Doppler techniques, indicating a lasting blood flow increase following three alternating ozone therapy sessions (B. Clavo, personal communication). However, our hypothesis of an increase in tumor perfusion resulting from ozone therapy needs further confirmation with studies specifically addressing the effect on tumor blood flow using, for example, multichannel laser Doppler.

Techniques such as hyperbaric chambers or carbogen breathing plus nicotinamide can increase arterial $\mathrm{pO}_{2}$, with secondary tumor $\mathrm{pO}_{2}$ increase. Usually, however, this is less effective in modifying hypoxic areas and, as well, the effect is of a very short duration; of the order of 10-15 minutes (33). Furthermore, if applied for more than 15-30 min, these therapies can lead to vaso-constriction resulting in a potential blood-flow decrease, secondary to hyperoxia, in most organs (34) as well as in tumors (33). Our results show that, in the most hypoxic tumors, ozone therapy leads to an improvement in tissue $\mathrm{pO}_{2}$ for at least $48 \mathrm{~h}$ after the second session of therapy. Similarly, it should be noted that the hypoxic fraction was decreased for protracted periods. Nevertheless, better results could probably be achieved using combined therapies, principally, techniques to increase blood oxygenation.

On the other hand, metastatic or large-size tumors are probably not the best situations in which to evaluate oxygen delivery or the vascular effect of ozone therapy, as observed in anemia-modification studies (35). However, for the pur- pose of the present study, the patients selected were those with advanced cancer or with large affected nodes that were easily accessible to physical examination so as to facilitate the tumor $\mathrm{pO}_{2}$ measurements.

Tumor hypoxia predisposes to a physiologic selection of tumor cells with decreased apoptotic potential, which results in resistance to radiotherapy and chemotherapy (2), higher angiogenesis and a more aggressive tumor potential (3-5). If ozone therapy successfully decreases tumor hypoxia in some patients, it could be useful as an adjuvant in the treatment of these patients by improving tumor oxygenation, by reducing radio-resistance and improving local control. Survival could be improved by decreasing tumor hypoxia, as shown by Overgaard's meta-analyses (15). The results of the present study indicate that tumor $\mathrm{pO}_{2}$ modification could support the anecdotal clinical reports of an improved effect of radiotherapy in advanced tumors when ozone therapy is included in the schedule (36).

Radio-mimetic (37) and synergistic (38) effects of radiotherapy as well as growth inhibition of human cancer cells by ozone (39) and increase in chemo-sensitivity in colon carcinoma cells resistant to 5-fluorouracil (40) have been described; albeit, these effects of ozone are not directly applicable to human ozone therapy. However, from a clinical oncology point of view, further research needs to be conducted on the effects of ozone-enriched blood. The effects described in relation to increasing antioxidant (22-26) and cytokine production $(41,42)$ are particularly relevant. A review on the potential role of ozone therapy as a biological response modifier in oncology has been published by Bocci (43), and we concur with the view that the appropriate controlled clinical trials would be particularly valuable.

In conclusion, many aspects regarding the bio-medical application of ozone therapy remain unexplored. In the present prospective study, the effect of ozone therapy on human tumor $\mathrm{pO}_{2}$ has been measured using the polarographic probe technique, and the results indicate that ozone therapy could increase oxygenation in the most hypoxic tumors. This suggests the potential use of this therapy as adjuvant in chemo-radiotherapy schedules, and would warrant further investigation.

\section{Acknowledgments}

We thank Dr G. Rovira-Dupláa (Ozone therapy Unit, Quiron Clinic, Barcelona, Spain) for his invaluable help in the initial stages of our study and Martina Günderoth (Helzel Medical Systems, Kaltenkirchen, Germany) for the technical and scientific support in this study. Editorial assistance was provided by Dr Peter R. Turner, t-SciMed, Reus, Spain.

The Eppendorf $\mathrm{pO}_{2}$ Histograph 6650 device was purchased by a grant (FUNCIS PI: 31-98) from the Health and Research Foundation of the Autonomous Government of the Canary Islands (Spain). 


\section{References}

1. Gray LH, Conger AD, Ebert M, Hornsey S, Scott OCA. The concentration of oxygen dissolved in tissues at the time of irradiation as a factor in radiotherapy. Br J Radiol 1953;26:638-48.

2. Graeber TG, Osmanian C, Jacks T, Housman DE, Koch CJ, Lowe SW, et al. Hypoxia-mediated selection of cells with diminished apoptotic potential in solid tumors. Nature 1996;379:88-91.

3. Young SD, Marshall RS, Hill RP. Hypoxia induces DNA overreplication and enhances metastatic potential of murine tumor cells. Proc Natl Acad Sci U S A 1988;85:9533-7.

4. Brizel DM, Scully SP, Harrelson JM, Layfield LJ, Bean JM, Prosnitz LR, et al. Tumor oxygenation predicts for the likelihood of distant metastases in human soft tissue sarcoma. Cancer Res 1996;56:941-3.

5. Plasswilm L, Tannapfel A, Cordes N, Demir R, Hoper K, Bauer J, et al. Hypoxia-induced tumor cell migration in an in vivo chicken model. Pathobiology 2000;68:99-105.

6. Gatenby RA, Kessler HB, Rosenblum JS, Coia LR, Moldofsky PJ, Hartz WH, et al. Oxygen distribution in squamous cell carcinoma metastases and its relationship to outcome of radiation therapy. Int J Radiat Oncol Biol Phys 1988;14:831-8.

7. Brizel DM, Sibley GS, Prosnitz LR, Scher RL, Dewhirst MW. Tumor hypoxia adversely affects the prognosis of carcinoma of the head and neck. Int J Radiat Oncol Biol Phys 1997;38:285-9.

8. Nordsmark M, Overgaard J. A confirmatory prognostic study on oxygenation status and loco-regional control in advanced head and neck squamous cell carcinoma treated by radiation therapy. Radiother Oncol 2000;57:39-43.

9. Clavo B, Lloret M, Perez JL, Lopez L, Suarez G, Macias D, et al. Association of tumor oxygenation with complete response, anemia and erythropoietin treatment. J Clin Oncol 2002;21:443 (abst.).

10. Hockel M, Schlenger K, Aral B, Mitze M, Schaffer U, Vaupel P. Association between tumor hypoxia and malignant progression in advanced cancer of the uterine cervix. Cancer Res 1996;56:4509-15.

11. Sundfor K, Lyng H, Rofstad EK. Tumor hypoxia and vascular density as predictors of metastasis in squamous cell carcinoma of the uterine cervix. Br J Cancer 1998;78:822-7.

12. Brizel DM, Scully SP, Harrelson JM, Layfield LJ, Bean JM, Prosnitz LR, et al. Tumor oxygenation predicts for the likelihood of distant metastases in human soft tissue sarcoma. Cancer Res 1996;56:941-3.

13. Nordsmark M, Alsner J, Keller J, Nielsen OS, Jensen OM, Horsman MR, et al. Hypoxia in human soft tissue sarcomas: adverse impact on survival and no association with p53 mutations. Br J Cancer 2001;84: $1070-5$.

14. Stone HB, Brown JM, Phillips TL, Sutherland RM. Oxygen in human tumors: correlations between methods of measurement and response to therapy. Summary of a workshop, National Cancer Institute, Bethesda, Maryland, November 19-20, 1992. Radiat Res 1993;136:422-34.

15. Overgaard J, Horsman MR. Modification of hypoxia-induced radioresistance in tumors by the use of oxygen and sensitizers. Semin Radiat Oncol 1996;6:10-21.

16. Rovira G, Galindo N. La ozonoterapia en el tratamiento de las úlceras crónicas de las extremidades inferiores. Angiologia 1991;2:47-50.

17. Romero A, Menéndez S, Gómez M, Ley J. La ozonoterapia en los estadios avanzados de la aterosclerosis obliterante. Angiologia 1993;45: $146-8$.

18. Giunta R, Coppola A, Luongo C, Sammartino A, Guastafierro S, Grassia A, et al. Ozonized autohemotransfusion improves hemorheological parameters and oxygen delivery to tissues in patients with peripheral occlusive arterial disease. Ann Hematol 2001;80:745-8.

19. Clavo B, Perez JL, Lopez L, Suarez G, Lloret M, Rodriguez V, et al. Effect of ozone therapy on muscle oxygenation. J Altern Complement Med 2003;9:251-6.

20. Clavo B, Perez JL, Lopez L, Suarez G, Lloret M, Morera J, et al. Influence of hemoglobin Concentration and peripheral muscle pO2 on tumor oxygenation in advanced head and neck tumors. Radiother Oncol 2003;66:71-4.

21. Vaupel P, Schlenger K, Knoop C, Hockel M. Oxygenation of human tumors: evaluation of tissue oxygen distribution in breast cancers by computerized O2 tension measurements. Cancer Res 1991;51:3316-22.
22. Hernandez F, Menendez S, Wong R. Decrease of blood cholesterol and stimulation of antioxidative response in cardiopathy patients treated with endovenous ozone therapy. Free Radic Biol Med 1995;19:115-9.

23. Bocci V. Does ozone therapy normalize the cellular redox balance? Implications for therapy of human immunodeficiency virus infection and several other diseases. Med Hypotheses 1996;46:150-4.

24. Leon OS, Menendez S, Merino N, Castillo R, Sam S, Perez L, et al. Ozone oxidative preconditioning: a protection against cellular damage by free radicals. Mediators Inflamm 1998;7:289-94.

25. Barber E, Menendez S, Leon OS, Barber MO, Merino N, Calunga JL, et al. Prevention of renal injury after induction of ozone tolerance in rats submitted to warm ischemia. Mediators Inflamm 1999;8:37-41.

26. Peralta C, Leon OS, Xaus C, Prats N, Jalil EC, Planell ES, et al. Protective effect of ozone treatment on the injury associated with hepatic ischemia-reperfusion: antioxidant-prooxidant balance. Free Radic Res 1999;31:191-6.

27. Bocci V, Valacchi G, Corradeschi F, Aldinucci C, Silvestri S, Paccagnini E, et al. Studies on the biological effects of ozone: 7. Generation of reactive oxygen species (ROS) after exposure of human blood to ozone. J Biol Regul Homeost Agents 1998;12:67-75.

28. Coppola L, Giunta R, Verrazzo G, Luongo C, Sammartino A, Vicario $\mathrm{C}$, et al. Influence of ozone on hemoglobin oxygen affinity in type-2 diabetic patients with peripheral vascular disease: in vitro studies. Diabete Metab 1995;21:252-5.

29. Verrazzo G, Coppola L, Luongo C, Sammartino A, Giunta R, Grassia $\mathrm{A}$, et al. Hyperbaric oxygen, oxygen-ozone therapy, and rheologic parameters of blood in patients with peripheral occlusive arterial disease. Undersea Hyperb Med 1995;22:17-22.

30. Valacchi G, Bocci V. Studies on the biological effects of ozone: 11. Release of factors from human endothelial cells. Mediators Inflamm 2000;9:271-6.

31. Kelleher DK, Hummel M, Vaupel P. Lack of tumor oxygenation improvement upon ozone therapy in experimental tumors. Strahlenther Onkol 2000;176:115 (abst.).

32. Vaupel P, Kallinowski F, Okunieff P. Blood flow, oxygen and nutrient supply, and metabolic microenvironment of human tumors: a review. Cancer Res 1989;49:6449-65.

33. Falk SJ, Ward R, Bleehen NM. The influence of carbogen breathing on tumor tissue oxygenation in man evaluated by computerised p02 histography. Br J Cancer 1992;66:919-24.

34. Bergo GW, Tyssebotn I. Cardiovascular effects of hyperbaric oxygen with and without addition of carbon dioxide. Eur J Appl Physiol Occup Physiol 1999;80:264-75.

35. Kelleher DK, Thews O, Vaupel P. Modulation of tumor oxygenation and radiosensitivity by erythropoietin. In Vaupel P, Kelleher DK (eds): Tumor Hypoxia. Stuttgart: Wissenschaftliche Verlagsgesellschaft 1999, 83-90.

36. Hernuss P, Muller-Tyl E, Dimopoulos J. [Ozone-oxygen injection in gynecological radiotherapy]. Strahlentherapie 1974;148:242-5.

37. Brinkman R, Lamberts HB. Ozone as a possible radiomimetic gas. Nature 1958;181:1202-3.

38. Fetner RH. Chromosome breakage in vicia faba by ozone. Nature 1958; 181:504-5.

39. Sweet F, Kao MS, Lee SC, Hagar WL, Sweet WE. Ozone selectively inhibits growth of human cancer cells. Science 1980;209:931-3.

40. Zanker KS, Kroczek R. In vitro synergistic activity of 5-fluorouracil with low-dose ozone against a chemoresistant tumor cell line and fresh human tumor cells. Chemotherapy 1990;36:147-54.

41. Bocci V, Paulesu L. Studies on the biological effects of ozone 1. Induction of interferon gamma on human leucocytes. Haematologica 1990; 75:510-5.

42. Bocci V, Luzzi E, Corradeschi F, Paulesu L, Di Stefano A. Studies on the biological effects of ozone: 3. An attempt to define conditions for optimal induction of cytokines. Lymphokine Cytokine Res 1993;12: 121-6.

43. Bocci V. Ozonetherapy as a possible biological response modifier in cancer. Forsch Komplementarmed (Research in Complementary Medicine) 1998;5:54-60. 


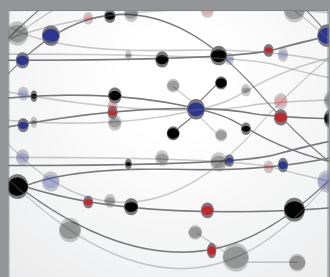

The Scientific World Journal
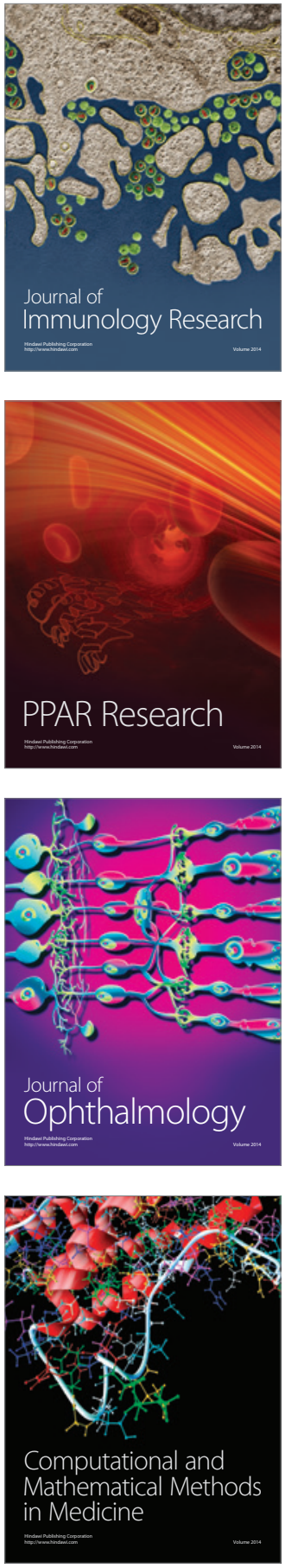

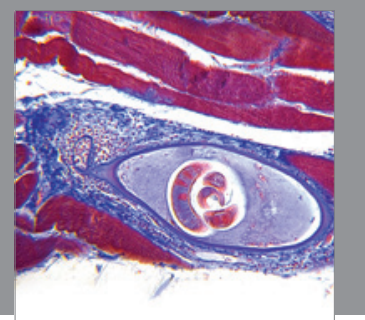

Gastroenterology

Research and Practice
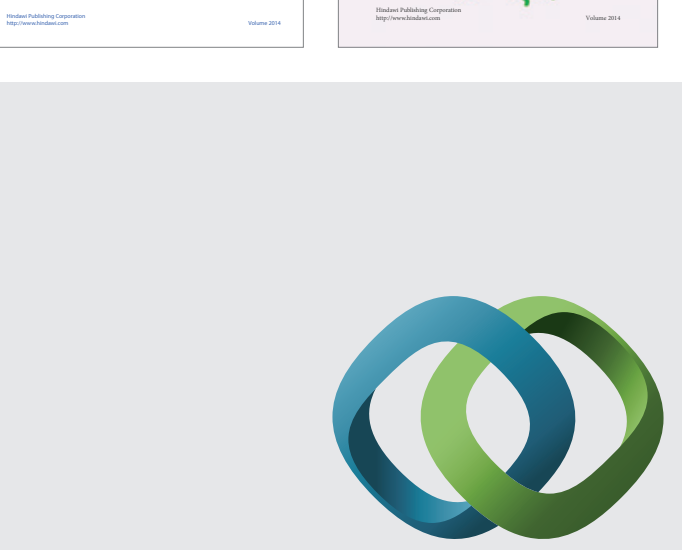

\section{Hindawi}

Submit your manuscripts at

http://www.hindawi.com
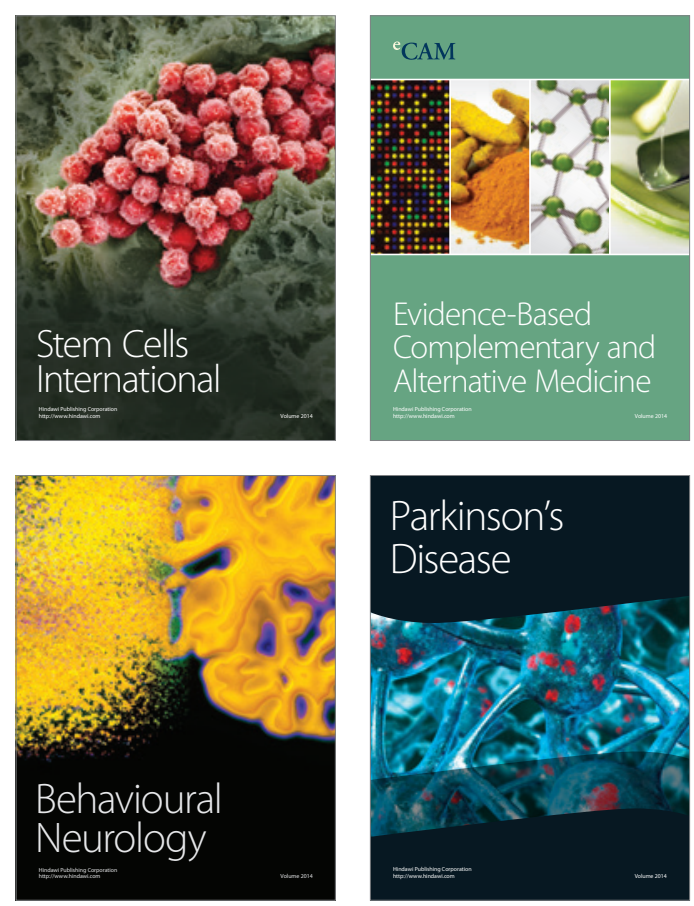

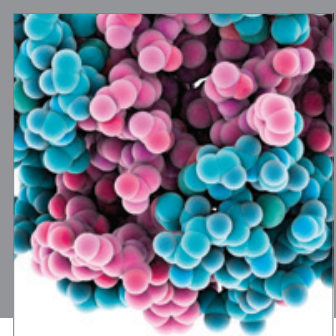

Journal of
Diabetes Research

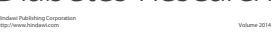

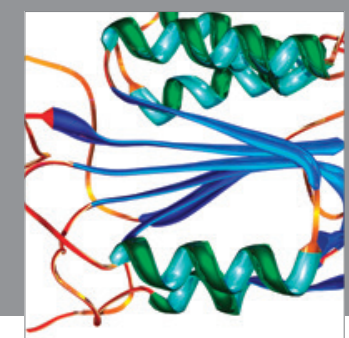

Disease Markers
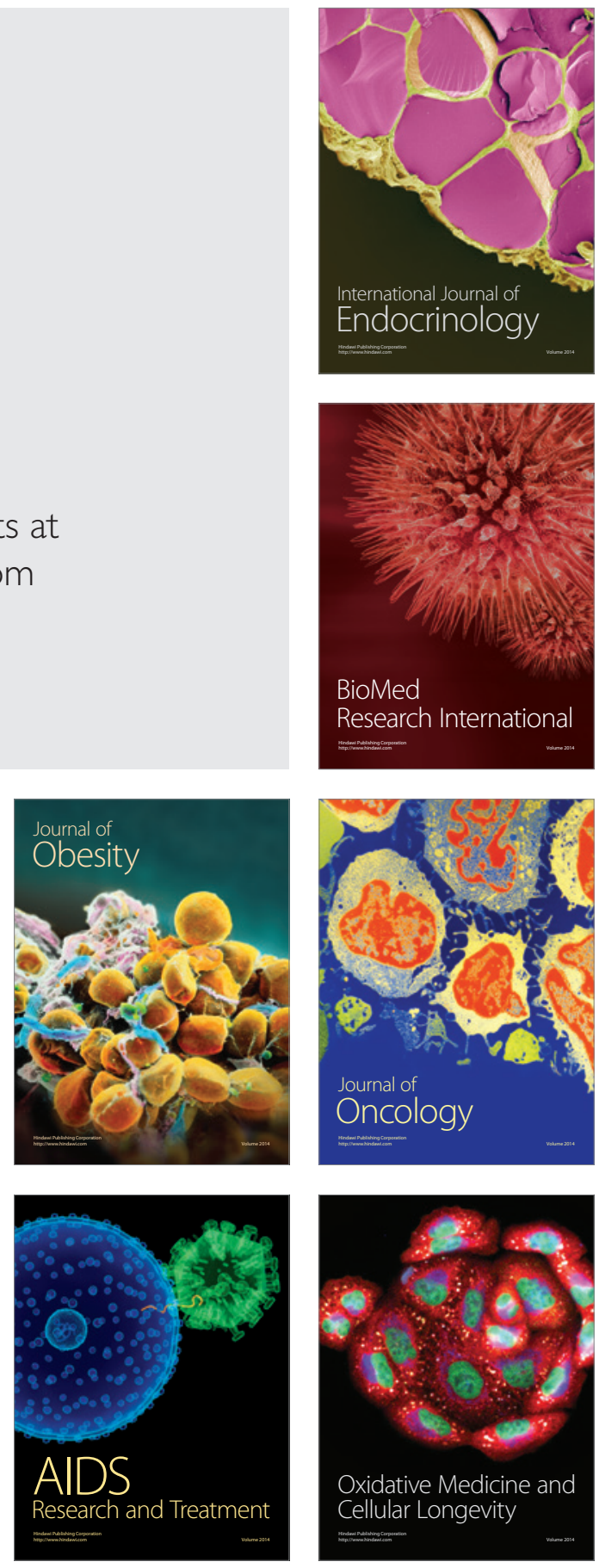